\title{
Analisa sumur resapan untuk mereduksi limpasan permukaan pada Perumahan Hang Tuah Cipta Residence Pekanbaru
}

\author{
Gandung Rahmadi ${ }^{1}$, Imam Suprayogi ${ }^{2}$, Joleha $^{3^{*}}$ \\ ${ }^{1}$ Alumni Jurusan Teknik Sipil, Fakultas Teknik, Universitas Riau \\ ${ }^{2,3}$ Dosen Jurusan Teknik Sipil, Fakultas Teknik, Universitas Riau \\ *Correspondent email:joleha@lecturer.unri.ac.id
}

Diterima: 02 Oktober 2021| Disetujui: 30 Oktober 2021 | Diterbitkan: 31 Oktober 2021

\begin{abstract}
Changes in land use, namely from cultivated land to closed land or settlements, make the water demand in the area increase, if the water that comes out is not balanced with the water that enters the ground, it will cause a decrease in the ground water level. Another problem that arises due to changes in land use is runoff, where runoff occurs due to rainfall exceeding the suction power or infiltration of the soil, so that over time the runoff becomes a puddle and can even cause flooding. One way to overcome these problems is to apply infiltration wells. This case study takes place in the Hang Tuah Cipta Residence Housing Area, Pekanbaru. From the results of field research and Hydrological data analysis revealed that the main existing drainage channel discharge with a discharge capacity of $0.923 \mathrm{~m}^{3} / \mathrm{s}$ is unable to accommodate the discharge that occurs at $1.19 \mathrm{~m}^{3} / \mathrm{s}$. Segment or secondary drainage channels Q12 and Q13 are also unable to accommodate the discharge that occurs at $0.085 \mathrm{~m}^{3} / \mathrm{s}$ with a capacity of $0.06 \mathrm{~m}^{3} / \mathrm{s}$. Based on the analysis results it is planned that the infiltration well with a radius of $0.5 \mathrm{~m}$ and a depth of 9 $m$ which has a capacity of $0.0022 \mathrm{~m}^{3} / \mathrm{s}$. After the planned discharge infiltration well comes out to be 0.88 $\mathrm{m}^{3} / \mathrm{s}$, it means that the discharge does not exceed drainage capacity of $0.923 \mathrm{~m}^{3} / \mathrm{s}$.
\end{abstract}

Keywords: Runoff, Drainage Channels, Infiltration Wells

Perumahan Hang Tuah Cipta Residence, Tenayan Raya, Pekanbaru merupakan salah satu kawasan dengan kedalamaan muka air tanah jauh di dalam tanah, sehingga mengharuskan masyarakat menggunakan sumur dalam untuk memperoleh air bersih, sebaliknya genangan dan banjir terjadi pada saat musim hujan. Hasil Survey dan wawancara dengan masyarakat di Perumahan tersebut diperoleh informasi bahwa sumur yang digunakan masyarakat memiliki kedalaman rata-rata 60 meter dengan muka air tanah pada kedalaman 25-30 meter dari permukaan tanah.

Berdasarkan Peraturan Daerah Kota Pekanbaru Nomor 10 Tahun 2006 tentang sumber daya air dan sumur resapan dinyatakan bahwa salah satu pencegahan atau cara mengatasi genangan dan banjir adalah dengan menggunakan sumur resapan. Sumur resapan berfungsi untuk menampung dan meresapkan air, sehingga mengurangi limpasan permukaan pada saat musim hujan. Selain itu sumur resapan juga berfungsi untuk meninggikan muka air tanah serta air yang ditampung pada sumur resapan dapat menjadi cadangan pada saat musim kemarau.

Dalam merencanakan sumur resapan secara teknis menurut SNI 8456-2017 adalah di lokasi yang memiliki kedalaman air tanah $>2 \mathrm{~m}$, permeabilitas tanah yang dapat digunakan harus mempunyai nilai koefisien permeabilitas tanah $>2.0 \mathrm{~cm} / \mathrm{jam}$. Klasifikasi permeabilitas tanah dibagi menjadi sedang (jenis tanah lanau, 2,0 - 3,6 cm/jam atau 0,48-0,864 $\mathrm{m}^{3} / \mathrm{m}^{2} /$ hari), nilai permeabilitas tanah agak cepat (jenis tanah pasir halus, 3,6-36 cm/jam atau $0,864-8,64 \mathrm{~m}^{3} / \mathrm{m}^{2} /$ hari) dan nilai permeabilitas tanah cepat (jenis tanah pasir kasar, lebih besar $36 \mathrm{~cm} /$ jam atau $8,64 \mathrm{~m}^{3} / \mathrm{m}^{2} /$ hari).

Penempatan sumur resapan juga harus memperhatikan jarak terhadap bangunan. Jarak minimum sumur resapan air terhadap bangunan sumur resapan air hujan/sumur air bersih adalah $3 \mathrm{~m}$, terhadap pondasi bangunan adalah $1 \mathrm{~m}$ dan terhadap bidang resapan/tangka septik adalah $5 \mathrm{~m}$.

Tujuan penelitian ini adalah menghitung debit kawasan perumahan sebelum dan sesudah ada sumur resapan, menentukan disain dimensi sumur resapan menggunakan debit limpasan dari saluran eksisting pada kawasan perumahan tersebut, mengetahui besar limpasan yang terjadi sebelum dan sesudah adanya rencana sumur resapan, serta membuat grafik hubungan antara kedalaman sumur resapan yang dibutuhkan terhadap jari jari sumur resapan.

\section{METODE PENELITIAN}

Lokasi penelitian ini terletak di kawasan Perumahan Hang Tuah Cipta Residence, Tenayan Raya, Pekanbaru, seperti yang terlihat pada Gambar 1. 
ZONA

Jurnal Lingkungan

Volume 5, No 2, Oktober 2021, p. 66-76

ISSN : 2502-6496 (Print) | 2502-6496 (Online) http://zona.pelantarpress.co.id

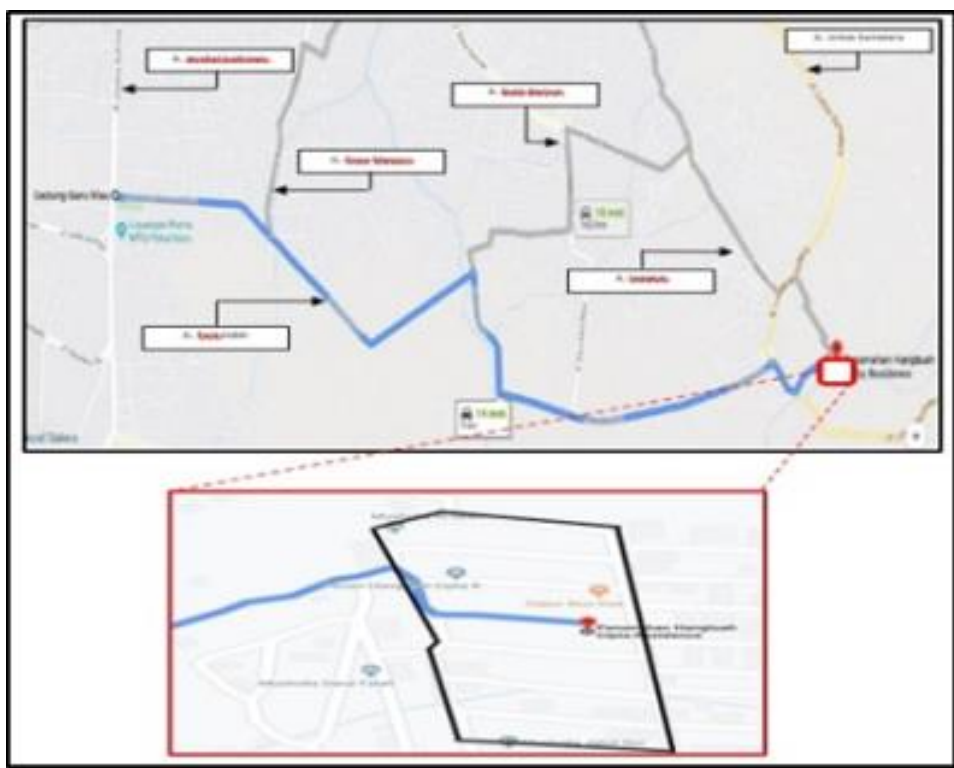

Gambar 1. Lokasi Penelitian (dimodifikasi dari google map, 2020)

Sedangkan alur penelitian yang dilaksanakan digambarkan pada Gambar 2, yang dirinci lebih lanjut dengan melakukan analisa-analisa sebagai berikut;

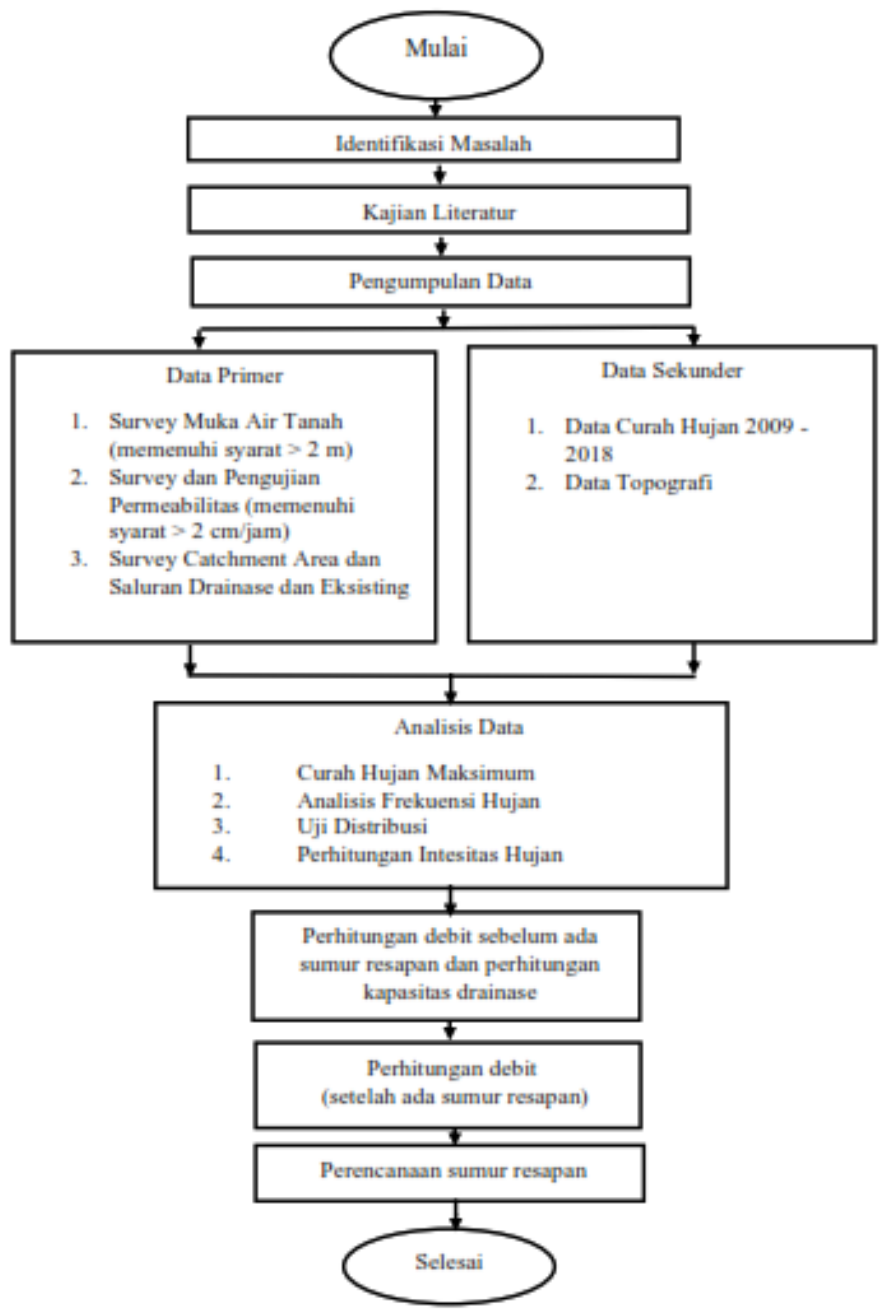

Gambar 2. Flowchart Metode Penelitian 
ZONA

Jurnal Lingkungan

ISSN : 2502-6496 (Print) | 2502-6496 (Online)

Volume 5, No 2, Oktober 2021, p. 66-76 http://zona.pelantarpress.co.id

\section{Analisis Hidrologi}

Data curah hujan yang akan dianalisis berupa kumpulan data tahun 2009-2018. Kejadian hujan merupakan proses stokastik, sehingga untuk keperluan analisa dan menjelaskan proses stokastik tersebut digunakan teori probabilitas dan analisa frekuensi (Upomo 2016). Perhitungan curah hujan rencana menggunakan data curah hujan dengan periode ulang tertentu yang dihitung dengan 4 metode distribusi frekuensi yaitu distribusi normal, distribusi log normal, distribusi log pearson III, dan distribusi Gumbel (Supriyani et al 2012). Adapun distribusi yang dipakai dapat ditentukan setelah mengetahui karakteristik data yang ada, yaitu data curah hujan rata-rata maksimum (Soemarto, 1987).

Sifat-sifat data yang tersedia sangat menentukan jenis analisis yang akan digunakan. Parameter statistik yang perlu diperhatikan antara lain :

a. Nilai rata-rata (Mean).

$$
\bar{X}=\frac{\sum_{\mathrm{i}=1}^{\mathrm{n}} \mathrm{Xi}}{\mathrm{n}}
$$

b. Nilai Deviasi standar (Standart Deviation)

$$
\mathrm{S}=\sqrt{\frac{\sum_{\mathrm{i}=1}^{\mathrm{n}}(\mathrm{xi}-\mathrm{x})^{2}}{\mathrm{n}-1}}
$$

c. Koefisien Variasi (Coefficient of Variation)

$$
\mathrm{CV}=\frac{\mathrm{s}}{\mathrm{X}}
$$

d. Koefisien Kemencengan (Coefficient of Skewness)

$$
\mathrm{Cs}=\frac{\mathrm{n} \sum_{\mathrm{i}=1}^{\mathrm{n}}(\mathrm{Xi}-\mathrm{X})^{3}}{(\mathrm{n}-1) \cdot(\mathrm{n}-2) \cdot \mathrm{S}^{3}}
$$

e. Koefisein Ketajaman (Coefficient of Kurtosis).

$$
\mathrm{Ck}=\frac{\mathrm{n}^{2} \sum_{\mathrm{k}}(\mathrm{Xi}-\mathrm{X})^{4}}{(\mathrm{n}-1) \cdot(\mathrm{n}-2) \cdot(\mathrm{n}-3) \cdot \mathrm{S}^{4}}
$$

Keterangan :

$$
\begin{array}{ll}
\overline{\mathrm{X}} & =\text { Curah hujan rata }- \text { rata daerah }(\mathrm{mm}) \\
\mathrm{n} & =\text { jumlah data pengamatan } \\
\mathrm{Xi} & =\text { Curah hujan di stasiun } \mathrm{i}(\mathrm{mm}) \\
\mathrm{Sd} & =\text { Standar deviasi (mm) } \\
\mathrm{CV} & =\text { Koefisien variasi (Coefficient of Variation) } \\
\mathrm{Cs} & =\text { Koefisien kemnecengan (Coefficient of Skewness) } \\
\mathrm{Ck} & =\text { Koefisien ketajaman (Coefficient of Kurtosis) }
\end{array}
$$

\section{Metode Rasional}

Metode yang umum dipakai untuk memperkirakan laju aliran permukaan adalah metode rasional (Suripin, 2004). Persamaan matematik metode Rasional dinyatakan dalam bentuk :

$\mathrm{Qp}=0,00278$. C . I . A

Keterangan :

Qp = Laju permukaan debit puncak $\left(\mathrm{m}^{3} /\right.$ detik)

$\mathrm{C}=$ Koefisien limpasan permukaan

I = Intensitas hujan $(\mathrm{mm} / \mathrm{jam})$

A $=$ Luas DAS (hektar)

\section{Waktu Konsentrasi $\left(t_{c}\right)$}

Waktu konsentrasi adalah waktu yang diperlukan oleh partikel air untuk mengalir dari titik terjauh didalam daerah tangkapan sampai titik yang ditinjau.

Waktu konsentrasi dapat dihitung dengan persamaan Kirpich dibawah ini :

$$
\begin{aligned}
& \mathrm{T}_{\mathrm{c}}=\left(\frac{0,87 \times \mathrm{L}^{2}}{1000 \times \mathrm{s}}\right)^{0}, 385 \\
& \mathrm{~L}=\sqrt{\left(\mathrm{a}^{2}+\mathrm{b}^{2}\right)}
\end{aligned}
$$

Keterangan

$\mathrm{T}_{\mathrm{c}}=$ Waktu konsentrasi

$\mathrm{S}=$ Kemiringan medan

$\mathrm{L}=$ Panjang lintasan aliran dipermukaan lahan $(\mathrm{km})$

$\mathrm{A}=$ Panjang Lahan $(\mathrm{km})$

$\mathrm{B}=$ lebar lahan $(\mathrm{km})$ 
ZONA

Jurnal Lingkungan

ISSN : 2502-6496 (Print) | 2502-6496 (Online)

Volume 5, No 2, Oktober 2021, p. 66-76 http://zona.pelantarpress.co.id

\section{Intensitas Hujan}

Intensitas hujan adalah tinggi atau kedalaman air hujan persatuan waktu. Sifat umum hujan adalah makin singkat hujan berlangsung, intensitasnya cenderung makin tinggi dan makin besar periode ulangnya makin tinggi pula intensitasnya (Suripin, 2004).

$I=\frac{R 24}{24}\left(\frac{24}{t}\right)^{2 / 3}$

Keterangan :

I $\quad=$ Intensitas hujan $(\mathrm{mm} / \mathrm{jam})$

$\mathrm{t} \quad=$ Lamanya hujan (jam)

R24 = Curah hujan maksimum harian (selama 24 jam) (mm)

\section{Saluran Drainase}

Perencanaan dimensi saluran drainase tergantung pada besarnya kapasitas aliran, yaitu jumlah air yang perlu dibuang, karakteristik saluran, dan keadaan topografi daerah.

$\mathrm{Q}=\mathrm{V}$. A

Keterangan:

$\mathrm{Q}=$ debit aliran $\left(\mathrm{m}^{3} /\right.$ detik $)$

$\mathrm{V}=$ kecepatan $\mathrm{rata}-$ rata saluran $(\mathrm{m} /$ detik $)$

$\mathrm{A}=$ luas penampang $\left(\mathrm{m}^{2}\right)$

\section{Permeabilitas Tanah}

Koefisien permeabilitas tanah, semakain tinggi nilai koefisien permeabilitas tanah maka semakin cepat kecepatan air untuk meresap. Nilai koefisien permeabilitas tanah berdasarkan klasifikasi jenis tanah pada seperti pada Tabel 1 (Braja, 1995).

Tabel 1. Koefisien Permeabilitas Tanah

\begin{tabular}{ccc}
\hline No & Jenis Tanah & $\mathrm{k}(\mathrm{cm} / \mathrm{s})$ \\
\hline 1 & Kerikil Bersih & $1,0-100$ \\
2 & Pasir Kasar & $1,0-0,01$ \\
3 & Pasir Halus & $0,01-0,001$ \\
4 & Lanau & $0,001-0,00001$ \\
5 & Lempung & Kurang dari 0,000001 \\
\hline
\end{tabular}

\section{Sumur Resapan}

Pada dasarnya sumur resapan berupa lubang - lubang galian yang dibuat di perkarangan atau diperkebunan, dan persawahan sebagai penampung air hujan. metode yang digunakan untuk perencanaan sumur resapan adalah metode Sunjoto (Sunjoto, 1989).

$\mathrm{Q}=5,5 \mathrm{~F} . \mathrm{K} \cdot \mathrm{H}$

$\mathrm{H}=\frac{\mathrm{Q}}{\mathrm{F} . \mathrm{K}}\left[1-\mathrm{e}^{\left(-\frac{\text { F.K.T }}{\pi \mathrm{R}^{2}}\right)}\right]$

Keterangan :

$\mathrm{Q}=$ Debit air masuk $\left(\mathrm{m}^{3} / \mathrm{dt}\right)$

$\mathrm{H}=$ Kedalaman sumur $(\mathrm{m})$

$\mathrm{F}=$ Faktor geometrik $(\mathrm{m})$

$\mathrm{K}=$ Koefisien permeabilitas tanah $(\mathrm{m} / \mathrm{dt})$

$\mathrm{T}=$ Durasi hujan $(\mathrm{dt})$

$\mathrm{R}=$ Jari - Jari sumur $(\mathrm{m})$

\section{HASIL DAN PEMBAHASAN}

Data curah hujan yang digunakan adalah data curah hujan harian maksimum tiap tahun dari stasiun penakar hujan. Curah hujan harian maksimum selama 10 tahunan yaitu dari 2009 - 2018 ditampilkan pada Tabel 2. 
Tabel 2. Data Curah Hujan Maksimum Harian Rata - Rata

\begin{tabular}{ccccc}
\hline \multirow{2}{*}{ No } & \multicolumn{3}{c}{ Kejadian } & Hujan Maksimum \\
\cline { 2 - 4 } & Tahun & Bulan & Hari & Harian Rata-Rata \\
\hline 1 & 2009 & 4 & 14 & 87,00 \\
2 & 2010 & 3 & 22 & 130,00 \\
3 & 2011 & 9 & 9 & 156,00 \\
4 & 2012 & 4 & 16 & 124,00 \\
5 & 2013 & 12 & 6 & 145,70 \\
6 & 2014 & 10 & 4 & 107,50 \\
7 & 2015 & 3 & 8 & 127,50 \\
8 & 2016 & 11 & 27 & 131,40 \\
9 & 2017 & 5 & 28 & 201,50 \\
10 & 2018 & 12 & 11 & 124,80 \\
\hline \multicolumn{5}{l}{ Sumber : Hasil Pengolahan Data, 2020 }
\end{tabular}

Dari Tabel 2 dapat dilihat curah hujan harian maksimum yang paling tinggi terjadi pada tahun 2017 hingga mencapai $201,50 \mathrm{~mm} /$ hari. Analisis distribusi hujan menggunakan persamaan 1-5 menghasilkan parameter statistik yang memenuhi persyaratan Distribusi Log-Normal dengan nilai Cs $=1,0186$ dan $\mathrm{Ck}=$ 6,192. Sehingga metode distribusi yang dipakai adalah metode Log-Normal dengan rumus (Suripin, 2004):

$$
\mathrm{Y}_{\mathrm{T}}=\overline{\mathrm{Y}}+\mathrm{K}_{\mathrm{T}} \mathrm{S} \text {. }
$$

Tabel 3 adalah hasil perhitungan untuk beberapa periode ulang.

Tabel 3. Hasil Perhitungan Data Hujan Dengan Distribusi Log Normal

\begin{tabular}{cccccc}
$\begin{array}{c}\text { Periode } \\
\text { Ulang }\end{array}$ & $\mathrm{Y}$ & $\mathrm{KT}$ & $\mathrm{S}$ & $\mathrm{Y}=\log \mathrm{XTr}$ & $\mathrm{XTr}$ \\
\hline T2 & 2,1159 & 0 & 0,0960 & 11,4281 & 130,6012 \\
T5 & 2,1159 & 0,84 & 0,0960 & 12,5401 & 157,2536 \\
T10 & 2,1159 & 1,28 & 0,0960 & 13,1651 & 173,3196 \\
T20 & 2,1159 & 1,64 & 0,0960 & 13,6996 & 187,6780 \\
T50 & 2,1159 & 2,05 & 0,0960 & 14,3347 & 205,4849 \\
T100 & 2,1159 & 2,33 & 0,0960 & 14,7854 & 218,6071 \\
\hline
\end{tabular}

Sumber : Hasil Pengolahan Data, 2020

\section{Debit Rencana}

Untuk menghitung debit rencana pada saluran drainase Perumahan Hang Tuah Cipta Residence dengan luas Catchment Area seperti yang tertera pada Gambar 3 yaitu seluas 2,38 ha. Untuk luas DAS < 10 ha, maka Perhitungan intensitas hujan menggunakan periode ulang 2 tahun $=130,6012 \mathrm{~mm} /$ hari (Tabel 3). Dengan Menggunakan persamaan 7 dan 8, diperoleh waktu konsentrasi $(t c)=0,0739$ jam dari panjang lahan $0,238 \mathrm{~km}$ dan lebar $0,1 \mathrm{~km}$. Selanjutnya perhitungan nilai Intensitas hujan menggunakan persamaan 9 , diperoleh Intensitas Hujan (I) sebesar $=257,137 \mathrm{~mm} / \mathrm{jam}$. Data-data ini digunakan untuk perhitungan debit rencana menggunakan persamaan 6. 
ZONA

Jurnal Lingkungan

ISSN : 2502-6496 (Print) | 2502-6496 (Online)

Volume 5, No 2, Oktober 2021, p. 66-76 http://zona.pelantarpress.co.id

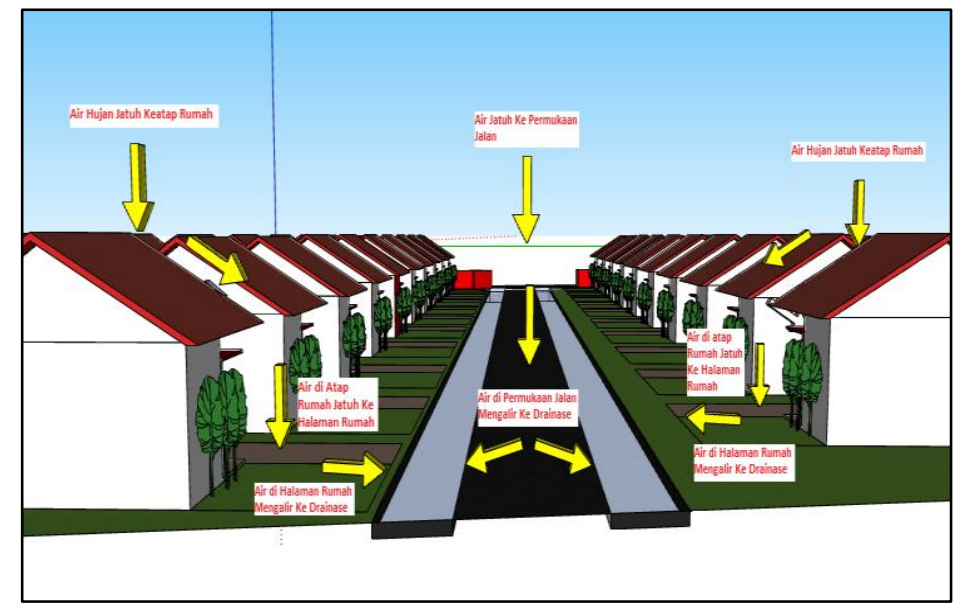

(b)

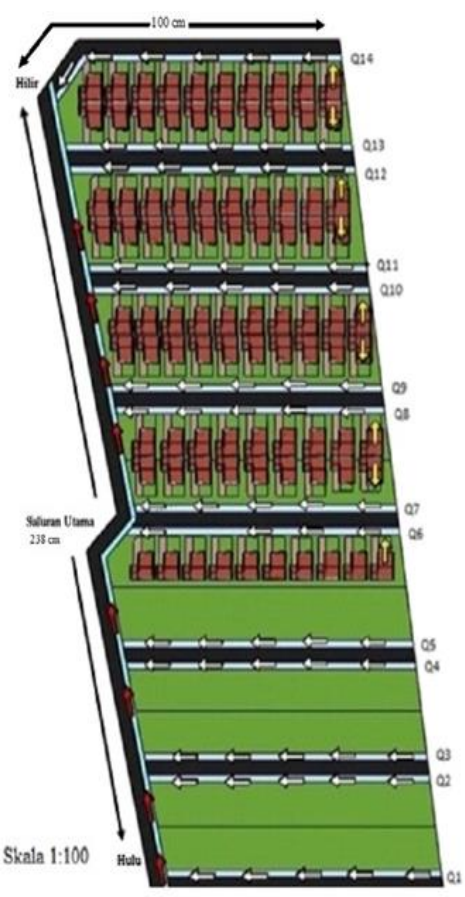

(a)

Gambar 3. Tampak Atas (a) dan samping (b) Arah Aliran dan Pembagian Segmen Drainase Perumahan Hang Tuah Cipta Residence (dimodifikasi dari google map dan ilustrasi, 2020)

Perhitungan debit rencana dilakukan untuk masing-masing segmen, diperoleh hasil perhitungan seperti pada Tabel 4.

Tabel 4. Rekapitulasi Hasil Perhitungan Debit Rencana

\begin{tabular}{|c|c|c|c|c|c|}
\hline No. & $\begin{array}{l}\text { Segmen } \\
\text { Saluran }\end{array}$ & $\mathrm{C}$ & $\begin{array}{c}\mathrm{I} \\
(\mathrm{mm} / \mathrm{Jam})\end{array}$ & $\begin{array}{c}\text { A } \\
\text { (ha) }\end{array}$ & $\begin{array}{c}\text { QR } \\
\left(\mathrm{m}^{3} / \mathrm{dt}\right)\end{array}$ \\
\hline \multicolumn{6}{|c|}{ Saluran Pengumpul } \\
\hline 1 & SU & 0,7 & 257,1368 & 2,38 & 1,190 \\
\hline \multicolumn{6}{|c|}{ Saluran Penerima } \\
\hline 2 & Q1 & 0,7 & 257,1368 & 0,19 & 0,095 \\
\hline 3 & Q2 & 0,7 & 257,1368 & 0,17 & 0,085 \\
\hline
\end{tabular}


ZONA

Jurnal Lingkungan

Volume 5, No 2, Oktober 2021, p. 66-76

ISSN : 2502-6496 (Print) | 2502-6496 (Online) http://zona.pelantarpress.co.id

\begin{tabular}{rrrrrr}
\hline 4 & Q3 & 0,7 & 257,1368 & 0,15 & 0,075 \\
5 & Q4 & 0,7 & 257,1368 & 0,16 & 0,080 \\
6 & Q5 & 0,7 & 257,1368 & 0,18 & 0,090 \\
7 & Q6 & 0,7 & 257,1368 & 0,18 & 0,090 \\
8 & Q7 & 0,7 & 257,1368 & 0,17 & 0,085 \\
9 & Q8 & 0,7 & 257,1368 & 0,16 & 0,080 \\
10 & Q9 & 0,7 & 257,1368 & 0,17 & 0,085 \\
11 & Q10 & 0,7 & 257,1368 & 0,17 & 0,085 \\
12 & Q11 & 0,7 & 257,1368 & 0,16 & 0,080 \\
13 & Q12 & 0,7 & 257,1368 & 0,17 & 0,085 \\
14 & Q13 & 0,7 & 257,1368 & 0,17 & 0,085 \\
15 & Q14 & 0,7 & 257,1368 & 0,18 & 0,090 \\
\multicolumn{5}{l}{ Total Saluran Penerima } \\
\multicolumn{5}{l}{ Sumber : Hasil Pengolahan Data,2020 } \\
\multicolumn{7}{l}{}
\end{tabular}

\section{Perhitungan Kapasitas Drainase}

Bentuk penampang saluran drainase di Perumahan tersebut adalah Persegi (Gambar 4) dengan konstruksi saluran beton, maka nilai koefisien Manning saluran tersebut adalah 0,014. Hasil perhitungan kapasitas drainase menggunakan persamaan 10 dapat dilihat pada Tabel 5.
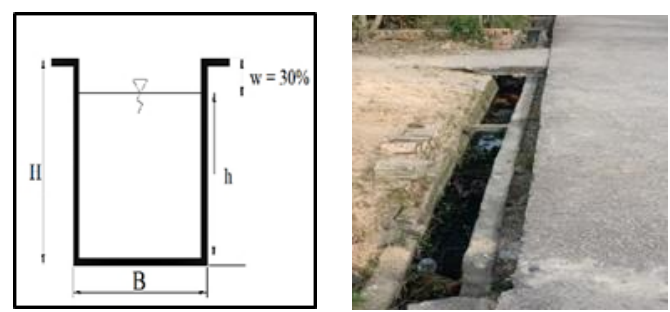

Gambar 4. Bentuk Penampang Saluran Eksisting Perumahan Hang Tuah Cipta Residence (Survey Lapangan, 2020)

Tabel 5. Perbandingan Kapasitas Saluran (QEks) Dengan Debit Rencana (QR)

\begin{tabular}{|c|c|c|c|}
\hline Saluran & $\begin{array}{c}\mathrm{QR} \\
\left(\mathrm{m}^{3} / \mathrm{det}\right)\end{array}$ & $\begin{array}{c}\text { QEks } \\
\left(\mathrm{m}^{3} / \mathrm{det}\right)\end{array}$ & Kondisi \\
\hline \multicolumn{4}{|c|}{ Saluran Pengumpul } \\
\hline SU & 1,19 & 0,92 & Melimpas \\
\hline \multicolumn{4}{|c|}{ Saluran Penerima } \\
\hline Q1 & 0,095 & 0,54 & Tidak Melimpas \\
\hline Q2 & 0,085 & 0,46 & Tidak Melimpas \\
\hline Q3 & 0,075 & 0,46 & Tidak Melimpas \\
\hline Q4 & 0,080 & 0,28 & Tidak Melimpas \\
\hline Q5 & 0,090 & 0,28 & Tidak Melimpas \\
\hline Q6 & 0,090 & 0,28 & Tidak Melimpas \\
\hline Q7 & 0,085 & 0,28 & Tidak Melimpas \\
\hline Q8 & 0,080 & 0,23 & Tidak Melimpas \\
\hline Q9 & 0,085 & 0,22 & Tidak Melimpas \\
\hline Q10 & 0,085 & 0,14 & Tidak Melimpas \\
\hline Q11 & 0,080 & 0,13 & Tidak Melimpas \\
\hline Q12 & 0,085 & 0,06 & Melimpas \\
\hline Q13 & 0,085 & 0,06 & Melimpas \\
\hline Q14 & 0,090 & 0,18 & Tidak Melimpas \\
\hline
\end{tabular}

Sumber : Hasil Pengolahan Data, 2020

Dari perbandingan hasil analisis data di atas dapat diketahui bahwa terjadi limpasan pada saluran drainase utama, saluran drainase sekunder Q12 dan Q13. Untuk mengurangi limpasan tersebut maka direncanakan pembuatan sumur resapan namun tidak hanya di segmen yang melimpas tapi di setiap rumah 
yang ada di Perumahan Hang Tuah Cipta Residence, karena selain untuk mengurangi limpasan sumur resapan juga dapat sebagai konservasi air tanah yakni meninggikan muka air tanah di kawasan tersebut, dan air yang disimpan didalam sumur juga dapat menjadi cadangan air.

\section{Perencanaan Sumur Resapan Individu}

Debit yang masuk dalam sumur resapan dihitung dari setiap rumah dengan type 36/62 yang terdiri dari luas atap/bangunan dan halaman, untuk tipe rumah yang ada di Perumahan Hang Tuah Cipta Residence diasumsikan sama type meskipun rumah tersebut sudah di tambah atau renovasi. Berdasarkan data survey lapangan, diperoleh nilai koefisien limpasan rata-rata Crata-rata $=0,49$. Debit maksimum $(\mathrm{Q}$ max) dari setiap rumah dihitung menggunakan rumus rasional, menghasilkan nilai sebesar $0,0022 \mathrm{~m}^{3} / \mathrm{dt}$.

Pengujian laboratorium dilakukan untuk memperoleh data Permeabilitas tanah yang digunakan untuk perhitungan kedalaman sumur resapan. Data hasil pengujian permeabilitas tanah dirangkum dalam Tabel 6. Dengan mengasumsikan durasi hujan selama 3600 detik, perhitungan perencanaan sumur resapan dengan percobaan berbagai diameter dapat dihitung dengan menggunakan persamaan 11 dan 12 . Kedalaman sumur resapan menggunakan jari-jari sumuran sebesar 0,5 meter menghasilkan factor geometrik sebesar 2,8 meter. Sehingga dengan data-data ini dibutuhkan kedalaman sumuran sebesar 9 meter untuk menampung debit limpasan $0,0022 \mathrm{~m}^{3} / \mathrm{dt}$.

Perhitungan debit resap adalah perhitungan untuk mencari nilai debit resapan yang terjadi, perhitungan debit sumur sebagai berikut: Qresap = F.K.H

$=2,8 \times 0,000016 \times 9$

$=0,0004 \mathrm{~m}^{3} / \mathrm{dt}$.

Tabel 6. Hasil Pengujian Permeabilitas Tanah

\begin{tabular}{|c|c|c|c|c|c|c|c|c|c|}
\hline No & Sampel & $\begin{array}{l}\text { Tinggi } \\
\text { Sampel } \\
(\mathrm{cm})\end{array}$ & $\begin{array}{l}\text { Diameter } \\
\text { Sampel } \\
(\mathrm{cm})\end{array}$ & $\begin{array}{l}\text { Diameter } \\
\text { Buret } \\
\text { (cm) }\end{array}$ & $\begin{array}{l}\text { No } \\
\text { Alat }\end{array}$ & $\begin{array}{l}\mathrm{h} 1 \\
(\mathrm{~cm})\end{array}$ & $\begin{array}{l}\text { Waktu } \\
\text { (detik) }\end{array}$ & $\begin{array}{l}\mathrm{h} 2 \\
(\mathrm{~cm})\end{array}$ & $\begin{array}{l}\text { Koefisien } \\
\text { (cm/det) }\end{array}$ \\
\hline \multirow{7}{*}{1} & \multirow{4}{*}{ Permukaan } & \multirow{4}{*}{5,8} & \multirow{4}{*}{6,4} & \multirow{4}{*}{1,4} & \multirow{4}{*}{7} & 65 & 60 & 11,8 & 0,0078838 \\
\hline & & & & & & 65 & 60 & 12 & 0,0078062 \\
\hline & & & & & & 65 & 60 & 13,3 & 0,0073309 \\
\hline & & & & & & 63,7 & 300 & 21,2 & 0,0012677 \\
\hline & \multirow[t]{3}{*}{ Dalam } & \multirow[t]{3}{*}{6,3} & \multirow[t]{3}{*}{6,4} & \multirow[t]{3}{*}{1,5} & \multirow[t]{3}{*}{8} & 63,7 & 300 & 22 & 0,0012250 \\
\hline & & & & & & 63,7 & 300 & 20,7 & 0,0012952 \\
\hline & & & & & & 65 & 900 & 19,2 & 0,0006606 \\
\hline \multirow{5}{*}{2} & \multirow[t]{3}{*}{ Permukaan } & \multirow[t]{3}{*}{10,2} & \multirow[t]{3}{*}{6,4} & \multirow[t]{3}{*}{1,4} & \multirow[t]{3}{*}{7} & 65 & 900 & 18,6 & 0,0006778 \\
\hline & & & & & & 65 & 900 & 22,3 & 0,0005795 \\
\hline & & & & & & 63,7 & 14400 & 62,5 & 0,0000004 \\
\hline & \multirow[t]{3}{*}{ Dalam } & \multirow[t]{3}{*}{6,2} & \multirow[t]{3}{*}{6,4} & \multirow[t]{3}{*}{1,5} & \multirow[t]{3}{*}{8} & 62,5 & 14400 & 60,6 & 0,0000007 \\
\hline & & & & & & 60,6 & 14400 & 59,3 & 0,0000005 \\
\hline & & & & & & 65 & 900 & 49,6 & 0,0001005 \\
\hline \multirow{5}{*}{3} & \multirow[t]{3}{*}{ Permukaan } & \multirow[t]{3}{*}{7} & \multirow[t]{3}{*}{6,4} & \multirow[t]{3}{*}{1,4} & \multirow[t]{3}{*}{7} & 49,6 & 900 & 31,7 & 0,0001664 \\
\hline & & & & & & 31,7 & 900 & 13,1 & 0,0003285 \\
\hline & & & & & & 65 & 14400 & 64,1 & 0,0000003 \\
\hline & \multirow[t]{2}{*}{ Dalam } & \multirow[t]{2}{*}{5,5} & \multirow[t]{2}{*}{6,4} & \multirow[t]{2}{*}{1,4} & \multirow[t]{2}{*}{7} & 64,1 & 14400 & 62,9 & 0,0000003 \\
\hline & & & & & & 62,9 & 14400 & 61,5 & 0,0000004 \\
\hline
\end{tabular}

Sumber : Hasil Pengolahan Data, 2020

Debit Yang Dapat Ditampung Oleh Sumur Resapan

Perhitungan ini dilakukan untuk mengetahui debit yang dapat ditampung sumur setelah didapat nilai debit resapan, perhitungan debit yang tertampung sebagai berikut :

Qtampung $=$ Qrencana - Qresap

$$
=0,0022-0,0004
$$

$=0,00176 \mathrm{~m}^{3} / \mathrm{dt}$

Sedangkan waktu yang diperlukan untuk pengisian sumur resapan adalah;

Tsumur = V / Qtampung

$=7,0 / 0,00176$

$=3996,301$ detik

$=1$ jam 6 menit

\section{Penempatan Sumur Resapan}


ZONA

Rencana penempatan sumur pada rumah di Perumahan Hang Tuah Cipta Residence sesuai dengan standart dan hasil pengukuran survey di lapangan dapat dilihat pada Gambar 5.
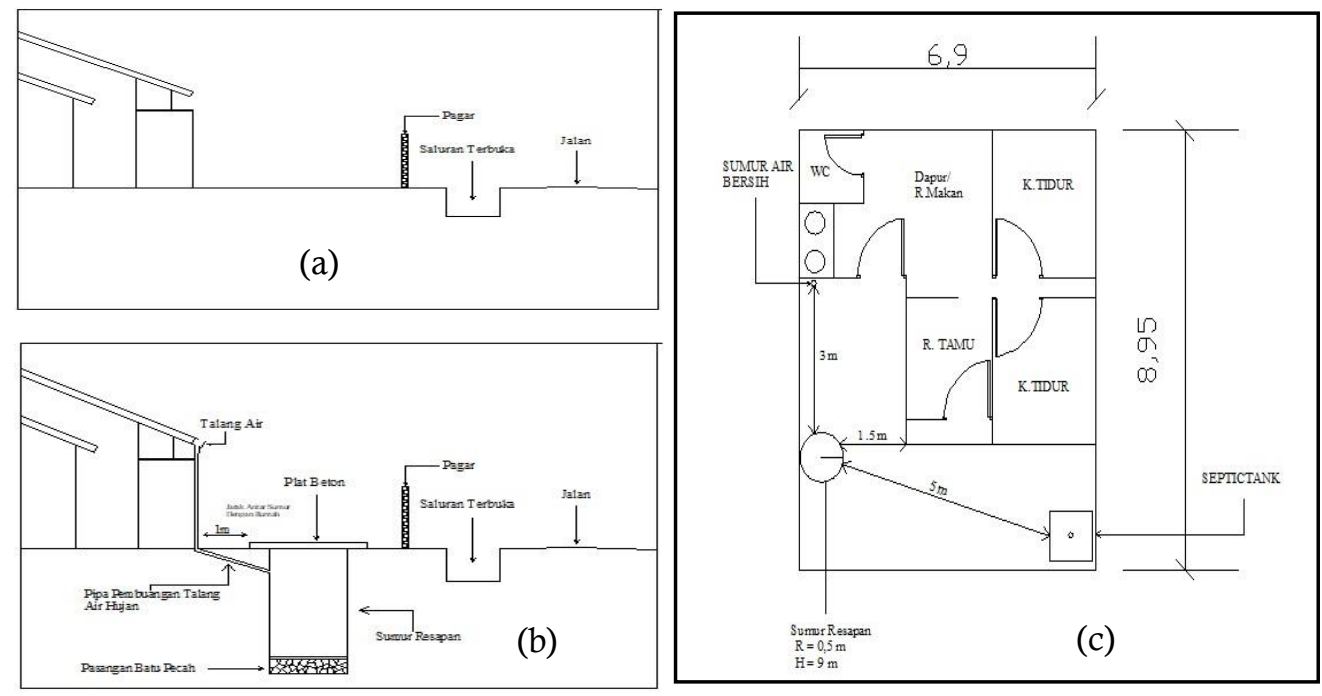

Gambar 5. Perencanaan sumur resapan pada rumah (a) sebelum ada sumur resapan, (b) setelah ada sumur resapan dan (c) denah rencana perletakan sumur resapan

\section{Evaluasi Debit Sebelum Ada Sumur Resapan dan Sesudah Ada Sumur Resapan}

Diketahui untuk drainase saluran Utama dari hasil analisis debit rencana dengan intensitas 257,137 $\mathrm{mm} / \mathrm{jam}$, yaitu $1,19 \mathrm{~m}^{3} / \mathrm{dt}$, lalu direncanakan sumur resapan, dianalisis debit setiap rumah $0,0022 \mathrm{~m}^{3} / \mathrm{dt}$, untuk kawasan Perumahan Hang Tuah Cipta Residence yang terdiri dari 143 kepala keluarga, maka debit yang masuk ke saluran utama setelah ada sumur resapan sebesar

$$
\begin{aligned}
\text { Q keluar } & =1,19 \mathrm{~m}^{3} / \mathrm{dt}-\left(0,0022 \mathrm{~m}^{3} / \mathrm{dt} \times 143 \mathrm{rumah}\right) \\
& =1,19 \mathrm{~m}^{3} / \mathrm{dt}-0,31 \mathrm{~m}^{3} / \mathrm{dt} \\
& =0,88 \mathrm{~m}^{3} / \mathrm{dt}
\end{aligned}
$$

Hasil perhitungan pada setiap saluran dapat dilihat pada Tabel 7.

Tabel 7. Rekapitulasi Debit Sisa Pada Masing - Masing Saluran Drainase

\begin{tabular}{cccccc}
\hline Saluran & $\begin{array}{c}\text { Debit } \\
\text { Rencana } \\
\left(\mathrm{m}^{3} / \mathrm{det}\right)\end{array}$ & $\begin{array}{c}\text { Debit } \\
\text { Sumur } \\
\text { Resapan } \\
\left(\mathrm{m}^{3} / \mathrm{det}\right)\end{array}$ & $\begin{array}{c}\text { Banyaknya } \\
\text { Rumah Per Blok }\end{array}$ & $\begin{array}{c}\text { Debit tampungan } \\
\text { sumur resapan } \\
\left(\mathrm{m}^{3} / \mathrm{det}\right)\end{array}$ & $\begin{array}{c}\text { Debit yang } \\
\text { masuk pada } \\
\text { drainase } \\
\left(\mathrm{m}^{3} / \mathrm{det}\right)\end{array}$ \\
\hline \multicolumn{2}{l}{ Saluran Pengumpul } \\
I-II & 1,19 & 0,0022 & & & \\
Saluran Penerima & 0,095 & 0,0022 & - & - & \\
Q1 & 0,085 & 0,0022 & - & - & 0,095 \\
Q2 & 0,075 & 0,0022 & - & - & 0,085 \\
Q3 & 0,080 & 0,0022 & - & - & 0,075 \\
Q4 & 0,090 & 0,0022 & - & 0,032 & 0,080 \\
Q5 & 0,090 & 0,0022 & 15 & 0,032 & 0,050 \\
Q6 & 0,085 & 0,0022 & 15 & 0,034 & 0,053 \\
Q7 & 0,080 & 0,0022 & 16 & 0,032 & 0,046 \\
Q8 & 0,085 & 0,0022 & 15 & 0,032 & 0,053 \\
Q9 & 0,085 & 0,0022 & 15 & 0,032 & 0,053 \\
Q10 & 0,080 & 0,0022 & 15 & 0,037 & 0,048 \\
Q11 & 0,085 & 0,0022 & 17 & 0,037 & 0,048 \\
Q12 & 0,085 & 0,0022 & 17 & 0,039 & 0,051 \\
Q13 & 0,090 & 0,0022 & 18 & 0,308 & 0,882 \\
Q14 & 1,19 & & 143 & & \\
\hline Total & & & & - & \\
\hline
\end{tabular}

Sumber : Hasil Pengolahan Data, 2020

Setelah direncanakan sumur resapan dengan kedalaman $9 \mathrm{~m}$ dan jari - jari 0,5 $\mathrm{m}$ pada kawasan Q12 dan Q13 yang awalnya memiliki debit rencana $0,085 \mathrm{~m}^{3} / \mathrm{dt}$ kemudian berubah menjadi $0,048 \mathrm{~m}^{3} / \mathrm{dt}$, artinya debit setelah direncanakan sumur resapan menjadi lebih kecil dari kapasitas drainase yang hanya dapat menampung $0,06 \mathrm{~m}^{3} / \mathrm{dt}$ disegmen tersebut, dan debit yang masuk kesaluran utama yang awalnya melimpas 
ZONA

dengan debit rencana $1,19 \mathrm{~m}^{3} / \mathrm{dt}$ dan kapasitas daya tampung drainase $0,923 \mathrm{~m}^{3} / \mathrm{dt}$ setelah direncanakan sumur resapan debit yang masuk pada saluran utama menjadi $0,88 \mathrm{~m}^{3} / \mathrm{dt}$.

Beberapa alternatif kedalaman dan jari - jari lainnya telah dihitung sebagai alternatif perencanaan desain sumur. Hasil perhitungan dirangkum pada Tabel 8.

Tabel 8. Analisis Perhitungan Perencanaan Sumur Resapan

\begin{tabular}{cccccccc}
\hline No & $\begin{array}{c}\text { R Jari- } \\
\text { Jari }(\mathrm{m})\end{array}$ & $\begin{array}{c}\text { Faktor } \\
\text { Geometrik } \\
(\mathrm{m})\end{array}$ & $\begin{array}{c}\mathrm{D} \\
\text { Diameter } \\
(\mathrm{m})\end{array}$ & $\begin{array}{c}\text { Q Debit } \\
\text { Rencana } \\
\left(\mathrm{m}^{3} / \mathrm{det}\right)\end{array}$ & $\begin{array}{c}\text { K } \\
\text { Permeabilitas } \\
(\mathrm{m} / \mathrm{det})\end{array}$ & $\begin{array}{c}\text { Durasi } \\
\text { Hujan } \\
(\mathrm{det})\end{array}$ & $\begin{array}{c}\mathrm{H} \\
\text { Kedalaman } \\
(\mathrm{m})\end{array}$ \\
\hline 1 & 0,5 & 2,8 & 1,0 & & & & 9 \\
2 & 1,0 & 5,5 & 2,0 & & & & 2 \\
3 & 1,5 & 8,3 & 3,0 & 0,0022 & 0,000016 & 3600 & 1 \\
4 & 2,0 & 11 & 4,0 & & & & 0,6 \\
5 & 2,5 & 14 & 5,0 & & & & 0,4 \\
\hline
\end{tabular}

Sumber : Hasil Pengolahan Data, 2020

Dari Tabel 8 dapat dilihat bahwa semakin kecil jari-jari sumuran maka kedalaman sumur resapan semakin panjang. Pilihan yang terbaik tentunya menyesuaikan dengan luas lahan yang tersedia dan estetika yang diinginkan. Untuk mempermudah melihat hubungan jari-jari sumuran dan kedalaman sumur resapan maka digambarkan dalam bentuk grafik pada Gambar 6.

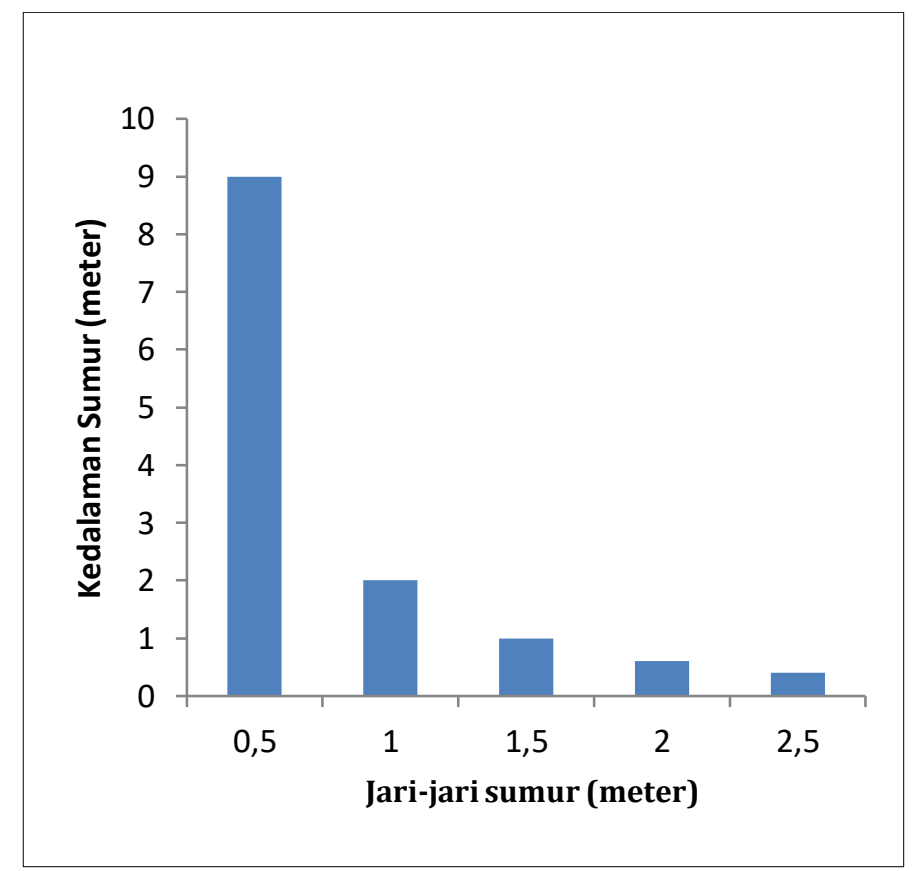

Gambar 6. Grafik Hubungan Antara Kedalaman dan Jari - Jari

\section{KESIMPULAN}

Berdasarkan data dan analisis yang telah dilakukan maka diketahui bahwa debit saluran eksisting utama dengan kapasitas tampung sebesar $0,923 \mathrm{~m}^{3} / \mathrm{dt}$ tidak mampu menampung debit yang terjadi sebesar $1,19 \mathrm{~m}^{3} / \mathrm{dt}$. Kapasitas saluran sekunder Q12 dan Q13 sebesar $0,06 \mathrm{~m}^{3} / \mathrm{dt}$ juga tidak memadai untuk menampung debit rencana sebesar $0,085 \mathrm{~m}^{3} / \mathrm{dt}$. Dengan adanya rancangan sumur resapan, maka dari hasil hitungan diperoleh debit yang keluar menjadi $0,88 \mathrm{~m}^{3} / \mathrm{dt}$ artinya debit yang keluar tidak melebihi kapasitas daya tampung drainase $0,923 \mathrm{~m}^{3} / \mathrm{dt}$.

Berdasarkan hasil perhitungan beberapa variasi jari - jari sumur resapan, maka diperoleh hubungan antara jari - jari sumur dan kedalaman sumur. Jari-jari terkecil yang dihitung adalah 0,5 meter menghasilkan kedalaman sumur 9 meter. Jari-jari sumur terbesar yang dihitung adalah 2,5 meter menghasilkan kedalaman terendah sebesar 0.4 meter. Pemilihan diameter sumur idealnya disesuaikan dengan luas lahan dan estetika yang diinginkan oleh pemilik lahan. 


\section{DAFTAR PUSTAKA}

Braja, M.D. (1995). Mekanika Tanah 1. Jakarta : Erlangga.

Departemen Pekerjaan Umum. (2006). Peraturan Pemerintah Republik Indonesia Nomor 34 Tahun 2006 Tentang Jalan. Badan Penerbit Pekerjaan Umum.

SNI: SNI 8456-2017. Sumur dan Parit Resapan Air Hujan

Soemarto. (1987). Hidrologi Teknik. Surabaya: Usaha Nasional.

Suripin. (2004). Sistem Drainase Perkotaan yang Berkelanjutan. Yogyakarta : Penerbit Andi

Sunjoto S.(1989). Teknik Konservasi Air pada Kawasan Permukiman.Yogyakarta (ID): LPM-UGM

Supriyani, E. Bisri, M. \& Dermawan, V. (2012). Studi pengembangan sistem drainase perkotaan berwawasan lingkungan. Jurnal Teknik Pengairan. 3(2):112-121.

Upomo, TC, Kusumawardani, R. (2016). Pemilihan distribusi probabilitas pada analisa hujan dengan metode goodness of fit test. Jurnal Teknik Sipil dan Perencanaan. 18(2):139-148. 